\title{
Financializáció a globális gazdaságban: okok és következmények CZELLENG ÁDÁM
}

A financializáció a pénzügyi tevékenységek, a pénzügyi piacok és a pénzügyi intézmények gazdaságban betöltött növekvö szerepét jelenti. A financializáció a kapitalizmusfejlödés természetes velejárója ugyan, számos tényezö azonban gyorsitotta a folyamatot. Ilyen többek között a dereguláció és a technológiai fejlödés, míg más olyan tényezök, amelyeket gyakran okozatként taglalnak - mint a globalizáció, a közvetitörendszer szerepének csökkenése és a vállalati konszolidáció -, a szerzö véleménye szerint a financializáció következményei. Érvelése szerint a financializációban keresendő számos olyan korábban a normálistól eltérönek gondolt jelenség, amely napjaink gazdaságát jellemzi: a globálisan egységesen alacsony, söt negatív kamatkörnyezet, a kockázatokat nem feltétlenül tükrözö hozamok, az új monetáris politikai eszközök és transzmissziós mechanizmusok. ${ }^{*}$

Journal of Economic Literature (JEL) kód: E00, E42, E44, E58, G15.

A következő elemzés célja, hogy bemutassa azon tényezők és események sorát, amelyek a sokáig a normálistól eltérőnek tekintett, napjainkban azonban mégis mindennapos pénzügyi jelenségekhez vezettek. Ilyen a klasszikus pénzügyi elméleteken kívül eső jelenség többek között a globálisan alacsony, sőt negatív kamatkörnyezet, az alacsony kockázatú országok állampapírjainak magasabb hozama a kockázatosabb országok állampapírjainak hozamánál, valamint az új monetáris politikai eszközök és transzmissziós mechanizmusok megjelenése. Ezek a pénzügyi folyamatok jelenleg is a kutatások középpontjában állnak, azonban fontos látni, hogy nem önál-

* A cikk korábbi változataihoz füzött értékes megjegyzéseiért a szerző köszönettel tartozik Karsai Gábornak, Molnár Lászlónak, Veres Máténak, Voszka Évának, valamint a tanulmány anonim lektorainak.

https://doi.org/10.47630/KULG.2018.62.7-8.100

Czelleng Ádám, a GKI Gazdaságkutató kutatásvezetője és a Szegedi Tudományegyetem PhDhallgatója. E-mail: czelleng.adam@gmail.com 
ló, egymástól függetlenül létező jelenségekről van szó, hanem szorosan összefonódó tényezők eredményeként jöttek létre.

A cikk sorra veszi az elmúlt évtized eseményeit, azonban nem egyszerủen kronologikusan kívánja bemutatni az eseményeket, hanem mélyebb magyarázatot keres a jelenségekre, amelyek megítélésem szerint a „financializációra” vezethetők viszsza, ami egyrészt a kapitalizmus fejlődése egyik természetes velejárójának tünik, miközben magának a financializációnak a gyors fejlödését a piacfundamentalista gazdaságpolitika támogatta.

A cikk első részében a financializáció bemutatását, terjedését segítő tényezőket kívánom bemutatni. A pénzügyi tevékenységek növekvő szerepét, térnyerését számos tényező támogatta, ilyen többek között a technológiai fejlődés, valamint a piacfundamentalista gazdaságpolitika és egyik keveset taglalt következménye az, hogy erősítette a gazdaságban a rövid távú szemléletet. Ezt követően pedig az elmúlt évek kutatásának középpontjában álló jelenségeket és azok financializációban rejlő gyökereit kívánom részletezni, vagyis azt, hogy melyek a financializáció jelenkori hatásai, hogyan vezetett a korábban elképzelhetetlennek gondolt negatív kamatokhoz, valamint hogy hogyan jelentek meg új monetáris politikai eszközök, amelyek új monetáris transzmissziós csatornákon keresztül hatnak a reálgazdaságra. Ahol lehetséges magyar, illetve nemzetközi példákon keresztül mutatom be a jelenségeket.

\section{Financializáció - erősíti a rövid távú szemléletet}

A financializáció a pénzügyi tevékenységek, a pénzügyi piacok és a pénzügyi intézmények gazdaságban betöltött növekvő szerepét jelenti. Bélyácz [2014, 28. o] megfogalmazása szerint a ,financializáción a pénzügyi piacok liberalizálását, a pénzfolyamatok globalizált, óriási mértékü növekedését és a gazdasági folyamatok pénzügyi alapon álló vezérlését értjük”. Krippner [2005] a financializáció bizonyítékát abban látja, hogy a pénzügyi szektor GDP-hozzájárulása az USA-ban az 1960as 15 százalékról 2000-re elérte a 23 százalékot, valamint míg 1980-ban a vállalati profitok 20 százaléka tartozott a pénzügyi szektorhoz, addig 2000-re ez az arány elérte a 40 százalékot. Kaplan és Rauh [2010] pedig a financializáció hatását azzal igazolta, hogy az öt legnagyobb hedge fund vezetöje 2004-ben többet keresett, mint az S\&P500 összes többi cégének vezérigazgatója együttvéve. Bresser-Pereira [2010] a financializáció folyamatának három jellemzőjét, megjelenési formáját különbözteti meg. Ezek 1) a reál és a pénzügyi szektor egymástól való elszakadása, 2) a pénz- 
ügyi intézmények profitrátájának tartósan magas szintje, 3) az értékpapírosításból eredően a pénzügyi instrumentumok sokszorozódása. Jelen tanulmány elsősorban ez utóbbi hatásait vizsgálja a financializáció kifejezés alatt, ettől eltérő értelmezés esetén erre a szövegben kitérünk.

Az elmúlt évtizedekben a pénzügyi piacok jelentős változásokon mentek át. Szunke [2014] öt olyan tényezőt azonosított, amely hozzájárult a folyamathoz. Ezek a globalizáció, a dereguláció, a közvetítőrendszer szerepének csökkenése, a technológiai fejlődés és a vállalati konszolidáció.

A deregulációt és a pénzügyi liberalizációt a financializáció folyamatát felerősítő tényezőként emelhetjük ki. Ez a pénzügyi intézmények és egyéb pénzügyi szolgáltatók korlátainak felszámolását jelentette a 80 -as és a 90 -es években. Erre példa az Egyesült Államok kapcsán az 1980-ban hatályba helyezett banki liberalizáció (Depository Institutions Deregulation and Monetary Control Act vagy röviden DIDMCA), illetve 1982-ben a jelzáloghitelek szabályozását érintő Garn-St. Germain-törvény, továbbá 1999-ben oldották fel a Glass-Steagall-törvényt, amely elöírta a kereskedelmi banki és a befektetési banki tevékenység szigorú szétválasztását (habár ez utóbbit a 2008-as válság után a Dodd-Frank pénzügyi piacszabályozási csomag részét jelentő Volcker-szabály próbálja pótolni). A dereguláció eredményeként a kereskedelmi bankok is egyre inkább pénzpiaci spekulációkba bonyolódtak. Az angolszász szakirodalomban „revolving door”-ként ismert jelenség pedig a bankok lobbitevékenységén keresztül a szabályozás további gátja (erről részletesen lásd: Cornaggia et al., 2016, Lucca et al., 2014, vagy Shive-Forster, 2016). Ez azt jelenti, hogy a politikai döntéshozókat azokból az intézményekből választják ki, amelyeket aztán politikusként adóztatniuk, szabályozniuk kellene. Sőt a politikai karrier után többnyire ezeknél a nagy cégeknél, bankoknál, intézményeknél helyezkednek el, így döntéseik során szem előtt tartják a szektor általi megbecsülésüket, jövőbeli karrierjüket.

Fontos tényező a financializáció terjedésében a technikai és technológiai fejlődés és a piaci konszolidáció. Az információs technológia (IT) fejlődése nagyban segítette az információ terjedését, a piacokhoz való azonnali hozzáférést, valamint megteremtette a szükséges technikai feltételeket új banki és pénzügyi termékek, innovációk létrejöttéhez és elterjedéséhez. A piaci konszolidáció a piac liberalizációjával és integrációjával egyre fokozta a versenyt a pénzügyi piacokon, s ennek eredményeként egyre növekedett az összeolvadások és felvásárlások száma. Így a vállalatok olyan nagyra nőttek, hogy már rendszerszintủ kockázatot jelentettek, ezt „too big to fail” problémának szokás nevezni. 
Számos tanulmányban a közvetítő szektor kiiktatása a pénzügyi tranzakciókból a financializációt elősegítő tényezőként jelenik meg (lásd: Dore, 2008, Szunke, 2014). Mivel a vállalatok közvetlenül is hozzáférnek a pénzügyi piacokhoz, így a közvetlen tőkepiaci finanszírozásnak egyre nagyobb az aránya. Az angolszász országok ebben a folyamatban elörébb járnak, általános jelenség azonban a közvetlen piaci finanszírozás fokozódása. Szorosan ide kapcsolódnak a pénzügyi innovációk is, hiszen a vállalatok új, saját kockázataik fedezésére kifejlesztett értékpapírokat bocsáthatnak ki. E cikk szerzője azonban French és Leyshon [2004] tanulmányának véleményét osztja, amely szerint a közvetítörendszer leépülése a financializáció következménye és nem pedig előidézője. Az információs technológiai fejlesztéseknek köszönhetően a piacok azonnali és közvetlen eléréséből eredően egyre csökkentek a tranzakció során a személyes kapcsolatok és az erre vonatkozó igények. A piacok fejlődése révén és az értékpapírok kereskedelmének és kibocsátásának könnyebbé, megszokottá válásával egyre kevésbé volt hangsúlyos a közvetítők szerepe a piacon.

Hasonlóan vitatott az oksági kapcsolat a globalizáció és a financializáció között. Számos tanulmány (lásd például: Guillén, 2014) érvelése szerint a globalizáció a pénzügyi piacok integrációját eredményezte, felerősítve a kapcsolatokat és az öszszefonódásokat a különböző országok és a különböző pénzügyi intézmények között. A pénzügyi piacok integrációját és a források mobilitását már az 1990-es évekbeli válságok után többen kritizálták, hiszen a kereskedelmi szektorban tapasztalt integrációtól eltérően nem volt érdemi fejlődés a pénzügyi piacokban és a funkcióikban (Bélyácz, 2014). A gyorsan áramló tőke nem feltétlenül hasznosul ugyanis, ugyanakkor strukturális problémákat képes okozni (Halmosi, 2004). Az ellenvéleményt képviselö tanulmányok (O’Rourke-Williamson, 1999, Rodrik, 2018, Velde, 2006) arra a következtetésre jutottak, hogy az okság épp fordított, tehát a financializáció segítette a globalizációt. Ezt az érvelést támasztja alá, hogy a világ az első világháború utáni globalizáltságát csak a 2000-es években érte el újra, ami - a piacfundamentális gazdaságpolitika és a dereguláció miatt - a pénzügyi piacoknak köszönhetően történt meg. A pénzügyi globalizáció ráadásul az országok tőkéért folytatott versenyét is gyorsította, így a tőkére kivetett adók is csökkentek, amelynek köszönhetően hosszú távú változások történtek és várhatóan történnek a jövőben a fiskális politika terén is (lásd: Razin et al., 2005, Razin-Sadka, 2018).

Ezek a tényezők természetesen nem önállóan, egymástól jól elkülöníthető tényezőként hatottak a financializációra, hanem szorosan összefonódtak, erősítették egymás hatásait. Például a technikai és technológiai fejlődés jelentősen hozzájárult a pénzügyi piacok integrációjához, vagy a dereguláció és a technológiai fejlödés 
jelentősen hozzájárult a pénzügyi innovációk globális elterjedéséhez, a mamutcégek létrejöttéhez és így tovább.

A financializáció eredményeként a globális pénzügyi eszközök értéke megsokszorozódott. Hasonlóan látványos következményként említhető a pénzügyi tevékenységet végző cégek közötti határvonal eltủnése, tehát míg korábban kizárólag pénzügyi vállalatok, bankok foglalkoztak hitelezéssel és pénzügyi eszközökbe való befektetéssel, addig ez mára ágazattól függetlenül megszokott lett. E tevékenységek rendszerint kiemelkedő profitot nyújtanak, így a pénzügyi intézmények profitrátájának tartósan magas szintje is megfigyelhető. Az S\&P500 indexet alkotó vállalatok profitrátája és az indexbe tartozó pénzügyi vállalatok megtérülési rátáját mutatja 1991 és 2016 között az 1. ábra, amelyen jól látszik, hogy a válság éveit leszámítva a pénzintézeti profitráta nagyjából a duplája az index összes cégének profitrátájának (miközben az átlag a magas profitrátájú pénzügyi vállalatokat is tartalmazza).

1. ábra

\section{Profitráta az S\&P összes és az S\&P pénzügyi cégei esetében 1991-2016 között} (Százalékban)

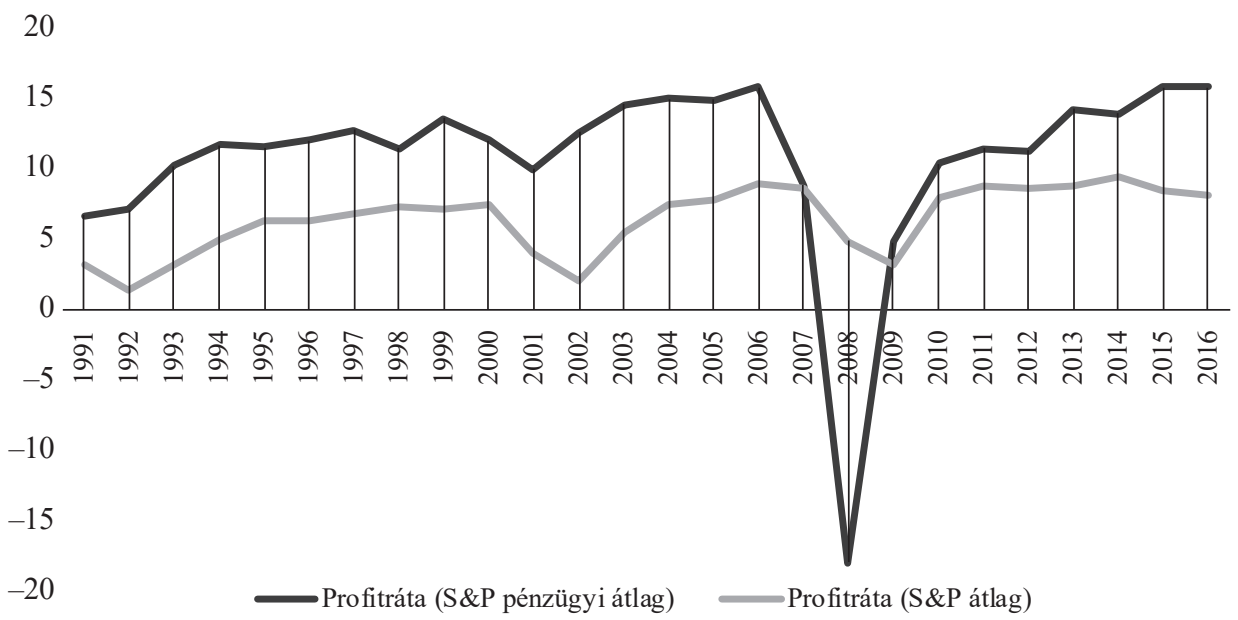

Forrás: Bloomberg.

Véleményem szerint a financializáció egyik fontos, a jelen cikkben bemutatott folyamatokat talán leginkább befolyásoló következménye - amivel azonban keveset 
foglalkozik a nemzetközi szakirodalom - a rövid távú szemlélet elterjedése. A pénzügyi szektor magas jövedelmezősége miatt a gyors megtérüléssel való kecsegtetés felváltotta a hosszú távú beruházási szemléletet. Fontos ugyanakkor megjegyezni, hogy a pénzügyi tranzakciók ,végén” reálgazdasági motívumok húzódnak meg. Egy kötvénykibocsátás is forráshoz jutást jelent, amire akár egy beruházáshoz lehet szükség. Továbbá a derivatív termékek is olyan kockázatokat hivatottak lefedni, amelyek valamilyen reálgazdasági motívumhoz kapcsolódnak (például a kibocsátott kötvények kamatkockázata, az export és az import devizaárfolyamnak való kitettsége). A reálgazdasági növekedés azonban jelentősen elmarad a pénzügyi piacokon tapasztalt növekedéstöl.

A financializáció eredménye, hogy a gazdasági élet szereplői képesek „kereskedni" a kockázataikkal, amelyet - az új környezethez való alkalmazkodás miatt - a bankrendszer is támogat, így a bankrendszer ezen funkciója egyre dominánsabbá válik (erről bővebben lásd: Allen és Santomero, 1997 és 2001). Zysman [1984] érvelése szerint a pénzügyi piacokról történő forrásszerzés, kockázatok fedezése növeli a vállalatok autonómiáját, hiszen nincsenek egy szereplőnek kiszolgáltatva. Ennek eredményeként azonban jelentősen csökkent a befektetők lojalitása, ami a befektetési hajlandóság csökkenésén, a kockázatéhség emelkedésén és a rövidebb távú szemléletben tükröződik (Engelen-Konings, 2008, valamint Hardie, 2008).

Ezt jól példázza a fejlődő országokba áramló tőke, hiszen szignifikáns és erős korreláció mérhető a feltörekvő országok tőkeáramlásában valamennyi befektetési kategóriában (vállalati hitelek, hazai fizetőeszközben denominált adósságok, ún. local currency és más fizetőeszközben denominált alapok, ún. hard currency).

A 2. ábra a fejlődő országok csoportjába sorolt országok kötvényalapjainak állományát mutatja be. Az ábrán jól látható, hogy az egyes bejelentésekkel fémjelzett periódusok rövid időszak alatt nagyon szignifikáns állományváltozást jelentettek a feltörekvő országok kötvényeinek piacán. Ezzel a rövid távú szemlélet erősödésével a financializáció komoly hatást gyakorol a devizaárfolyamokra és a refinanszírozási kockázatokra.

Az ezredforduló előtt a hazai szakirodalomban bontakozott ki vita a pénzügyi piacok túlburjánzásáról, illetve reálgazdasági szerepéről (lásd többek között: Csontos et al., 1997, Pete, 1999).

A financializáció a kapitalizmus fejlődésének természetes velejárója. Már a 19. században megkezdődött az értékpapírok jelentős terjedése, mivel a vállalatok közvetlen birtoklását felváltotta a vállalatok tulajdonrészére vonatkozó értékpapír tulajdonlása. Ez a technológia fejlődésével jelentősen felgyorsult, hiszen az 
információ elérhetősége, terjedése és az értékpapírok adás-vétele és elszámolása jelentősen könnyebbé vált a digitalizáció és az infokommunikációs technológiák fejlődésével.

2. ábra

\section{Fejlődő államok kötvényeinek tartására dedikált alapokba áramló tőke 2010 óta, kumulált összeg}

(Millió dollár)

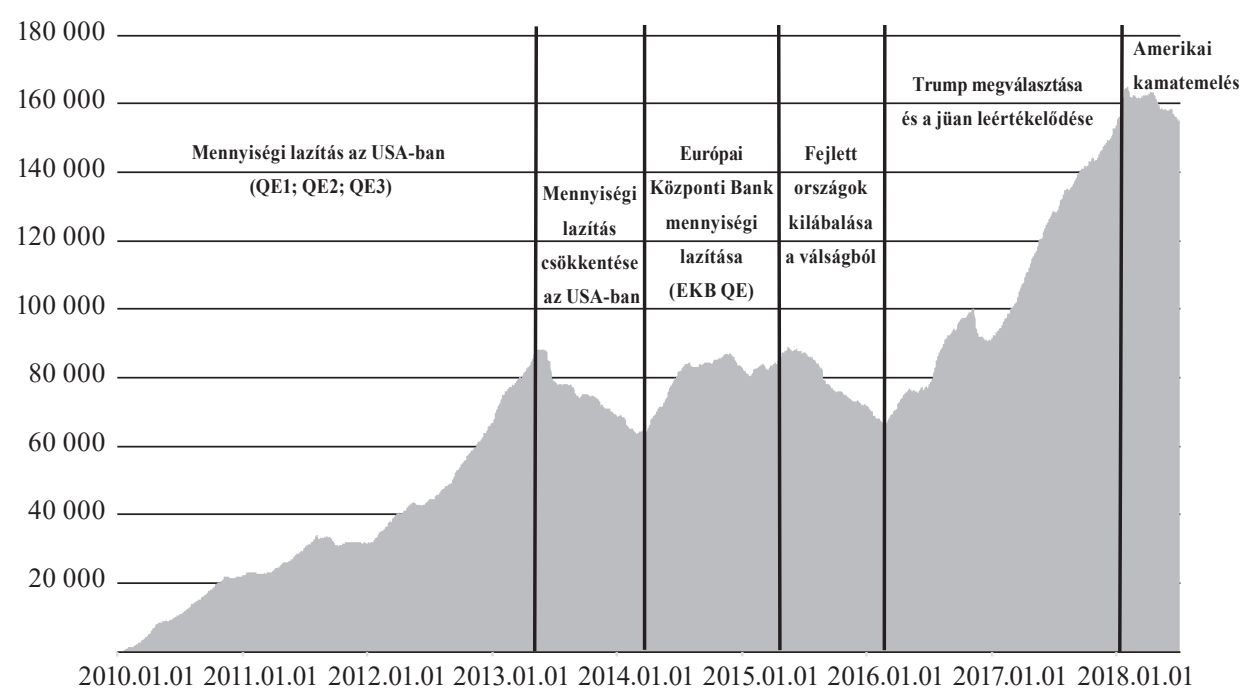

Forrás: Trounceflow és saját szerkesztés.

A financializáció folyamatát ugyanakkor jelentősen felgyorsította a neoliberális gazdaságpolitika. A 2. világháborút követő jelentős állami szerepvállalás és szabályozottság találkozott a stagfláció jelenségével, amelyből a neoliberális gazdaságpolitika vezette ki a világgazdaságot. Ez az időszak elsősorban a piaci erők érvényesítéséről, a korlátok eltörléséről szólt, ami a pénzügyi piacok deregulációját is magába foglalta (Kotz, 2008; Kotz és McDonough, 2008).

$J$. Tobin Nobel-díjas közgazdász megfogalmazása szerint „egyre több forrást fektetnek pénzügyi tevékenységbe a tényleges termelés helyett, ami nagyon magas profitot termel a töke tulajdonosának, ez pedig a társadalmi hasznosulással aránytalan" (Tobin, 1984, 14-15. o). A financializáció azon túl, hogy növeli a tár- 
sadalmi egyenlötlenségeket, növeli az információs aszimmetriát a pénzügyi termékek vásárlója és kínálója között; jelentősen aláássa a bankrendszer stabilitását és felgyorsítja az üzleti ciklusokat. Az üzleti ciklusok rövidülnek és volatilisebbé válnak (Szunke, 2014).

\section{Deflációs nyomás és a csökkenő, majd negatív kamatok}

A globális kamatkörnyezet már a válság előtti évtizedekben is csökkenő tendenciát mutatott. Ennek egyik oka, hogy a financializáció által gyorsított globalizációs folyamatokba becsatlakoztak a fejlődő országok, elsősorban Kína. Kína egyrészt az olcsó munkaerön keresztül jelentősen csökkentette az árakat, így mérsékelte az inflációt, másrészt a kínai megtakarítások, források is globálisan keresték a beruházási lehetőségeket.

A pénzügyi szektorban szerezhető kiemelkedő jövedelem, valamint a konglomerátumok létrejöttével a menedzsment egyre nagyobb mértékben gazdagodik, ami hozzájárult a jövedelmi különbségek elmélyítéséhez. A növekvő jövedelmi különbségek a társadalom egyes csoportjai között más demográfiai hatásokkal (a várható élettartam növekedésével és a gyerekszám csökkenésével, valamint a jövedelmek növekedésével) együtt jelentősen emelték az aggregált megtakarítások összegét, míg a beruházási lehetőségek nem tudták felszívni a megtakarításokat. A növekvő megtakarítások csökkenő beruházási lehetőségekkel szembesültek, hiszen jelentősen csökkent az innovációk száma (amit akár a hosszú távú szemlélet csökkenése is eredményezhetett). Néhány közgazdász egyenesen azt vallja, hogy az infokommunikációs technológiai forradalom lezajlását követően nincs igazi motorja a világgazdaságnak (Bean et al., 2015; Szanyi, 2018).

Ezt a folyamatot erősítette tovább a válság, illetve a gazdasági szereplők erre adott reakciója. A válság önmagában is a financializáció egyik következménye, hiszen az értékpapírosított jelzáloghitelek gyorsan terjedtek szét a világban. Receszszióban pedig tipikusan csökkennek a hiteltranzakciók, sőt csökkenhet a teljes hitelállomány is, miként ez a mostani válság során is történt. Ekkor ugyanis a gazdasági szereplők mérlegkiigazításra kényszerülnek, emellett a profitkilátások is jelentősen romlanak. Ezzel párhuzamosan csökkennek a kamatok és az árszínvonal. Az árszínvonal csökkenését a visszafogott kereslet okozza, ami miatt a gazdaság a potenciális kibocsátásnál lényegesen kisebb outputra képes. Ekkor tehát az úgynevezett output- 
gap deflációs vagy dezinflációs hatású. Az alacsony inflációs környezet és a gyenge hitelkereslet miatt pedig a kamatok is alacsony szintre kerülnek.

A válság hatásainak kifutásával - a kereslet visszaerősödésével - azonban egyre inkább szükségessé válik a kamatkörnyezet normalizálódása, mielött komoly reálhatásokkal fenyegető buborékok fújódnának fel a pénzügyi piacokon. A normalizálódás ugyanakkor komoly áldozatokkal is járhat. Az amerikai jegybank szerepét betöltő Fed - elsőként a fejlett országok jegybankjai közül - megkezdte kamatemelési ciklusát, amely az elmélet szerint több csatornán keresztül is negatívan hat a feltörekvő piacokra. A negatív hatások azonban egyelőre nem vagy csak korlátozottan jelentkeztek. Hosszú távon nem lehet berendezkedni a mostani kamatkörnyezetre.

Sokáig csak elméleti megfontolás volt a negatív kamat. 2012 közepén Dánia központi bankja átlépte a zéró kamatszintet. Ma már a 100 ezermilliárd dollár értékủ kötvénypiac több mint 10 százaléka negatív hozamú kötvényeket tartalmaz. A befektetésre ajánlott európai kötvények negyede ilyen, sőt már a vállalati kötvénypiacon is elkezdtek terjedni ezek az értékpapírok. 2012 júliusában az Európai Központi Bank a betéti kamatokat zérusra csökkentette. 2016 márciusában -0,4 százalékra csökkent az EKB-nál elhelyezett betétek kamata. Erre jól láthatóan azért került sor, mert a korábbi negatív kamat ellenére a bankközi piacon még pozitív kamatok érvényesültek, így az EKB nem tudta érvényesíteni a likviditás reálgazdaságba kiszorító hatását. Ez a csökkenés azonban a bankközi kamatokat is a negatív tartományba tolta.

A negatív kamatok melletti érvelés szerint a központi bank „megbírságolja” a nála többletlikviditást elhelyező kereskedelmi bankot, aminek hatására a bankok a többletet nem a központi banknál helyezik el, hanem megpróbálják hitelbe adni a háztartásoknak, a vállalatoknak vagy az államnak. A pénzből a háztartások fogyasztása megnő, a vállalatok több beruházást valósítanak meg, ezzel serkentve a növekedést és élénkítve az inflációt. A lakossági és a vállalati oldalon lévő korlátozott hitelkereslet miatt azonban ezek a források az állampapírpiacra terelődtek. A többletlikviditást a bankok a negatív kamatozású jegybanki betét helyett pozitív hozamú állampapírba fektették, így a többletforrás a továbbiakban az állampapírokat értékesítő bank ,problémája”. Mivel az aggregált bankrendszer többletlikviditása nem változik, így addig „,vándorolnak” a források, amíg a megnövekvő kereslet az állampapírok hozamát is negatív tartományba tolja.

Számos pénzügyi eszköznél azonban effektív korlátnak bizonyul a zéró kamat, hiszen ha a kereskedelmi bankok ráterhelnék a negatív kamatokat az ügyfelekre (a háztartásokra és a vállalatokra), akkor az emberek tömegesen vennék ki megtakarításaikat a bankokból. A betétesek jelentős tőkekivonása következtében akár össze 
is dőlhetne a pénzügyi rendszer. A pénzügyi stabilitás ugyanakkor első számú céllá lépett elő a válságot követően. A negatív kamat azonban komoly stabilitási kockázatot jelent, hiszen rontja a bankrendszer jövedelmezőségét. Emellett az alacsony kamatok miatt növekvő, részben felelötlen hitelfelvétel hatására tovább növekedne a nem teljesítő hitelek Európában amúgy is magas aránya, nem beszélve a különösen eladósodott dél-európai országokról, ahol az államcsőd veszélye is felvetődhetne.

Az alacsony hozamok amellett, hogy ösztönzőleg hatnak a beruházásokra, hatással vannak a megtakarításokra is. Egyrészt fokozottabb kockázatvállalásra késztetik a háztartásokat, másrészt az elöregedő társadalom biztos nyugdíjához emelni kell a megtakarításokat, ami a fogyasztás csökkentésével párhuzamosan mehet végbe. Mindez csökkentőleg is hathat a reálkeresletre. Több tanulmány empirikusan is igazolta, hogy a negatív kamatszint nem expanziós, hanem ellenkezőleg, restriktív hatású. Waller [2016] is a negatív kamatok kontraproduktív hatásaira hívja fel a figyelmet, amelyet egyenesen a bankrendszerre kivetett adóként értelmez. Eggerston et al. [2017] tanulmánya hat ország adataira támaszkodva bizonyítja, míg Heider et al. [2017] az eurózóna adatain igazolja a restriktív hatást. Eggerston et al. [2017] egy új-keynesi DSGE'-modellen keresztül is vizsgálta a negatív kamatok gazdaságra gyakorolt hatásait. Ennek alapján a csökkenő kamatok egy bizonyos szintig expanziós hatásúak, míg egy kitüntetett szint alatt már nincs keresletösztönző hatásuk, sőt a csökkenő profiton keresztül kifejezetten restriktív hatásúak. Hasonló eredményre jutott Gertler és Kiyotaki [2010] tanulmánya is.

Negatív kamat esetén értelemszerüen a befizetett összegnél kevesebbet kap viszsza a befektető. A nominális kamatnál azonban sokatmondóbb a reálkamat. A negatív kamat jelensége deflációs környezetben válik érdekessé, hiszen az ebben az esetben még biztosíthat pozitív reálkamatot. Ugyanakkor a monetáris politika mozgásterét a készpénz - melynek „kamata” nem módosítható - jelentősen korlátozza, hiszen a készpénz definiálható zéró kamatú értékpapírként is. Azonban a készpénz tartása és őrzése költséges, valamint a negatív kamatozású értékpapírok is biztosíthatnak többlethozamot, ha a kamatok tovább csökkennek, ekkor ugyanis árfolyamnyereség realizálható. Attól pedig, hogy az ilyen eszközöktől nem tudnak szabadulni a befektetők, jelen helyzetben nem kell tartani, hiszen a jegybankok a piaci szereplők mellett/helyett biztosítják a piac likviditását.

Egy pénzügyi eszköz nominális hozama három komponensből áll: az inflációból, a kockázatból, valamint az elvárt hozamból. A reálhozam a kockázatból és az

\footnotetext{
${ }^{1}$ Dinamikus sztochasztikus általános egyensúlyi modell.
} 
elvárt hozamból tevődik össze, így a reálhozam hosszú távon nem lehet negatív, különben nem megfelelően müködik a pénz- és tőkepiac.

Az EKB már több éve alkalmaz negatív kamatokat, hatása azonban sokáig nem érződött, hiszen évekig nem sikerült beindítani az inflációt, és minimális gazdasági növekedést sem tudott sokáig felmutatni az eurózóna. A 2016-2017-es évek során már az infláció és a gazdasági növekedés is beindulni látszik, a világgazdasági konjunktúra kivételesen kedvezőnek tekinthető. A negatív kamattal fémjelzett években fokozódott a bankok fizikai készpénztartása. Egyes országokban a betéti kamatokon kieső jövedelmet ráterhelték az ügyfelekre, így a betétesi oldalon éppen ellentétes hatást - kiadásnövekedést - ért el a negatív betéti kamat, valamint a hiteloldalon az egyéb költségek (járulékok) növelésével javították a bankok a csökkenő hitelkamatok miatt romló eredményességüket. A negatív kamat az eszközportfólió átrendezését okozta, így komoly robbanást eredményezett a kockázatos eszközök ${ }^{2}$ és az áruk piacán.

Miközben a monetáris kondíciók további lazítását indokolná az alacsony kereslet és az alacsony növekedési ütem, addig ez a klasszikus monetáris politikai eszközökkel már nem érhető el sem az eurózónában, sem az Egyesült Államokban. Ezt szokás likviditási csapdának nevezni. A jól ismert likviditási csapdához hasonlatos (sőt egyes közgazdászok szerint a likviditási csapda egy speciális, akut formája) a kockázatkerülési csapda. Ebben az esetben a gazdasági szereplők kockázatvállalási hajlandósága drasztikusan lecsökken, így megnő a kereslet a kockázatmentesnek ítélt értékpapírok irányába, ami zéró közelébe szorítja és tartósan ott is tartja a hozamszintet (részletesen lásd: Caballero-Farhi számos tanulmányát, például: CaballeroFarhi, 2017; valamint a hazai irodalomban: Horváth-Szini, 2015). A túlkereslet nem csak a kockázatvállalási hajlandóság csökkenésével alakulhat ki, hiszen a kockázatmentes pénzügyi eszközök számos gazdasági funkciót töltenek be. Amennyiben a kockázatmentes eszközök mennyisége nem elégséges a funkciók ellátásához, akkor is fennáll a csapdába kerülés végtelen spirálja. Ezen eszközöknek fontos szerepük van a befektetők portfóliódöntéseiben, fedezeti eszközként szolgálnak pénzügyi müveletek során (például: bankközi vagy jegybanki tranzakciók esetében), regulációs eszközként szolgálnak és egyik legfőbb szerepük, hogy a portfólióértékelés során alkalmazott benchmark funkciót töltik be (diszkontrátaként használatos). Termé-

${ }^{2}$ Sőt az alacsony kamatkörnyezetben befektetési alternatívák hiányában a globálisan áramló tőke és a kockázati étvágy segítette a kriptovaluták térnyerését, amelyek ugyan egyelőre nem számottevőek a pénzügyi rendszerben és elterjedésükhöz nagyobb reálgazdasági igény, főleg nagyobb politikai akarat szükséges, ezek megléte esetén azonban kriptovalutákhoz kapcsolódó technológiai újítások - mint a blokklánc és az okosszerződések - hosszú, esetleg már középtávon is segíthetik a pénz evolúcióját. 
szetesen a kínálati oldal csökkenése esetén is elöállhat a kockázatmentes eszközök iránti tartós túlkereslet, ahogy az a válság során meg is történt: az értékpapírosítás során kreált és korábban biztonságosnak ítélt és így a bankközi piacokon fedezetül szolgáló $\mathrm{CDO}-\mathrm{k}^{3}$ nagyon gyorsan kockázatosnak bizonyultak a válság kitörésekor, amivel párhuzamosan fokozódott is a biztonságra vonatkozó igény.

A kockázatkerülési csapdában a kockázatmentes eszközök iránti tartós túlkereslet nyomás alá helyezi a kamatokat, és akár negatív tartományban is tarthatja öket. Így nem képes kialakulni az optimális reálkamatszint, mivel az infláció eleve alacsony és a nominális kamatok zérus alá csökkennek. Így a gazdaság spirálba kerül. Ekkor ugyanis a csökkenő infláció növekvő reálkamatot eredményez, ami tovább csökkenő inflációhoz vezet és így tovább. Így a kritikus kamatszint elérése után az egyensúly már a reálgazdasági aktivitás csökkenésével próbál meg helyreállni. Vagyis a kockázatkerülési csapda esetében a monetáris kondíciók endogén szigorításáról beszélhetünk.

A kockázatkerülési csapdával szembenéző országok esetében tehát egy olyan, a pénzügyi elméletnek ellentmondó megfigyelést tehetünk, hogy a kockázatosabbnak ítélt országok hozamszintje alacsonyabb, mint a biztonságosabbnak gondolt országoké. Ilyen például a visegrádi országok közül Lengyelország és Magyarország. Miközben a lengyel adósság a hitelminősítők szerint jóval biztonságosabb, mint a magyar, Lengyelország mégis magasabb hozamszinttel kénytelen finanszírozni adósságait, mint a magyar kormányzat. Az ilyen országokban a kockázatmentes eszközök iránti igény a tőke külföldi eszközökbe áramlásával enyhül az árfolyamkockázat figyelembevételével, ami tovább növeli a pénzügyi piacok integrációját.

A likviditási csapda elkerülésére elsősorban a jegybank előretekintő üzenetei, a várakozások irányítása lehet hatékony, ezek azonban nem megfelelő eszközök a kockázatkerülési csapda esetében. Ezért a válságot követően a monetáris politika eszköztárának megújítására volt szükség.

\section{A monetáris politika új eszközei a financializáció nyomán}

Az elmúlt évtizedben a globális monetáris politika egyik meghatározó tényezője, hogy a jegybanki döntések egyre nagyobb mértékben befolyásolják a hosszú távú kamatokat. Ezt a jelenséget igazolta Hanson és Stein [2015] tanulmánya, amely

${ }^{3} \mathrm{CDO}$ (collateralized debt obligation): fedezett adósságkötelezvény (adósságlevél), többféle hitellel, kötvénnyel, ABS-sel fedezett kötvény. 
100 bázispontos jegybanki alapkamat-emelésre közel fél százalékpontos hosszú távú kamatemelést mutatott ki vektor-autoregressziós módszerrel. Ez elsősorban a rövid távú szemlélet elötérbe kerülésének, valamint a kereskedelmi bankok befektetési tevékenységének és a befektetési alapok térnyerésének következménye. A rövid távú szemlélet felerősödésével megjelenő hozamvadászat (lásd később) hatására a rövid lejáratú eszközök hozamváltozására a befektetők a portfólió kiigazításával reagálnak. Így a rövid lejáratú hozamok csökkenésénél felülsúlyozzák a hosszú lejáratú értékpapírokat, míg a rövid lejáratú hozamok emelkedésekor csökkentik a hosszú lejáratú értékpapírok súlyát a portfólióban. Ábel [2015] az ebből a jelenségből eredő stabilitási kockázatot hangsúlyozza, hiszen a rendkívül alacsony kamatkörnyezetben egy kismértékủ kamatemelés is veszteségbe fordíthatja a kötvénybefektetőket, és megfordíthatja a tőkeáramlás irányát. Ekkor nemcsak a befektetők hozamgörbén való elmozdulása figyelhető meg, hanem az eszközosztályok között is gyakori az átjárás, ahogyan az a mennyiségi lazítás következményeként már látható volt.

A válságot követően - a monetáris politika gyakorlatát empirikusan leíró Taylorszabály szerint - a Fed által meghatározott rövid lejáratú kamatok szintjének mélyen negatív tartományba kellett volna kerülnie. Ez azonban az ismertetett tényezők miatt problémákat vetett fel, így a monetáris politika eszköztára korlátokba ütközött.

Világszerte számos új innovatív eszköz jelent meg a monetáris kondíciók további lazítására, amelyek közül elsősorban két tényező determinálta a globális monetáris politikai trendeket. Ezek a mennyiségi és a minöségi lazitás (quantitative easing vagy $Q E$ és qualitative easing vagy QuaE).

A mennyiségi lazitás a monetáris bázis dinamikus növelését értékpapírok másodpiaci vásárlásával éri el, amelynek eredményeként jelentősen megnő a jegybank mérlege (lásd: Blinder, 2010; Chodorow-Reich, 2014; Joyce et al., 2012; Taylor, 2013). Elsőként a Bank of Japan alkalmazta a mennyiségi lazítást, amikor nagy tételben kezdett japán állampapírokat vásárolni 2001-ben. A mennyiségi lazítás során a központi bank jelzálogpapírokat és/vagy állampapírokat vásárol a bankoktól és értékpapír-kereskedőktől (úgynevezett árjegyzőktől), így az érintett értékpapírok piaca továbbra is likvid marad, sőt mi több, a megnövekedett kereslet miatt jelentősen megnő az árfolyamuk, azaz csökken az ilyen értékpapírok hozamszintje. Az európai bankrendszerben az elmúlt években elszámolt nyereség jelentős része az állampapírok felértékelődéséből származott. Ennek megfelelően egy majdani kamatemelés során a bankrendszernek ezeken majd veszteséget kell elszámolnia.

A felértékelődés következtében a befektetők és a bankok magasabb hozamot ígérő más jellegủ értékpapírba próbálnak befektetni. Ezt a jelenséget nevezik ho- 
zamvadászatnak, és ennek köszönhetően integrálódnak egyre inkább a különböző lejáratú vagy különböző pénzügyi eszközosztályok. Így a jegybank képes közvetlenül is hatni a hosszú távú hozamokra. Azokat alacsonyan tartva gyengíteni az ország fizetőeszközét, illetve az alacsony kamatokon keresztül ösztönözni a beruházásokat. Jellemzően a részvények, ingatlanok és mütárgyak értékében figyelhető meg jelentős növekedés a mennyiségi lazítás hatására. Az áremelkedésen elszámolt számviteli nyereséget a szereplők jellemzően visszaforgatták vagy megtakarították, így nem növekedett érdemben a reáljavak iránti kereslet. Azonban e piacoknak mégis fontos másodlagos hatásuk van. Ilyen például a vállalatfelvásárlásokra gyakorolt hatás, hiszen a megnövekedett részvényár nem jelent nagyobb értékteremtő képességet, ugyanakkor a felvásárláshoz jóval magasabb hitelösszeg szükséges. A növekvő részvényáron keresztül a vállalatok mérlegében módosul a hitel-saját tőke aránya, ami hitelkapacitások felszabadulását jelenti a vállalatok számára. Sőt a válságot követően jelentősen emelkedett a saját részvény visszavásárlása is, tehát a reálszféra is ide áramoltatott jelentős forrásokat. Ez szintén a rövid távú preferenciáknak köszönhető, ugyanis a vállalatvezetők teljesítményének értékelését a profitabilitást háttérbe szorítva a részvénypiac aktuális értékelése adja. A lakáspiaci áremelkedés is fokozta a jövedelmi átrendeződést a lakástulajdonosok és a lakást nem tulajdonlók között.

A mennyiségi lazítás kockázatának szokták tekinteni, hogy rejtett inflációt generál. Mivel a fogyasztói kereslet érdemben nem emelkedett, a fogyasztóiár-index sem változott szignifikánsan; az értékpapírok árfolyama és az ingatlanok értéke stb. azonban jelentősen emelkedett, ezek nem jelennek meg a klasszikus inflációs mutatószámokban. A mennyiségi lazítás egyik nagy elönye, hogy olcsóbbá válik az állam finanszírozása. Ugyanakkor ehhez felelösségteljes államra van szükség, hiszen az olcsó finanszírozhatóság ösztönözheti a túlzott eladósodást, puha költségvetési korlátot generálhat. A mennyiségi lazítás során tehát csökken az állam finanszírozásának költsége, s nincs szükség fiskális lazításra, eladósodásra. Ugyanakkor a jelenlegi helyzetben egy esetleg kirobbanó válság során nagyon nehéz lenne tovább növelni a jegybank mérlegét (legalábbis későbbi egyre nagyobb áldozatok nélkül). A jegybanki mérleg későbbi csökkentése pedig igencsak restriktív hatású lesz.

A nem konvencionális lazítás másik jellemző eszközét minőségi lazításnak nevezik. Ekkor a jegybank mérlegének összetétele a kockázatosabb, kevésbé likvid eszközök irányába tolódik el (Farmer, 2012). A minőségi lazítást is szokás a monetáris politika egyik eszközének tekinteni. Ugyanakkor Buiter [2010] érvelése szerint mivel ekkor az aggregált állam mérlegének kockázata növekszik - amit az adófize- 
tők fognak finanszírozni -, ezért akár fiskális vagy kvázi fiskális politikai eszköznek is felfogható.

A minőségi lazítás szakirodalma jóval szükebb, mint a mennyiségi lazításé, azonban a Magyar Nemzeti Bank által alkalmazott eszközök is beleillenek a minőségi lazítás fogalmába, ezért azok részletes bemutatásával illusztráljuk annak hatásait, következményeit, kockázatait. Az MNB a fejlett piacokon ismert mennyiségi lazításhoz hasonlóan az állampapírpiacok likviditásának növelésével igyekezett enyhíteni a monetáris kondíciókat. Fontos célja volt az is, hogy kiszámíthatóbbá, a világpiaci folyamatoktól függetlenebbé tegye a hazai folyamatokat, amit azonban nem közvetlen vásárlással, hanem többlet kockázatvállalással, a bankrendszer ösztönzésével, az eddig nála elhelyezett banki források állampapírpiacra terelésével érte el. Ez abból a szempontból indokolt is, hogy míg a válság előtt a bankrendszer eszközállományának 3-5 százalékát tartotta jegybanki betétben, addig ez az arány a válság végére megközelítette a 20 százalékot.

Az önfinanszírozási programmal összhangban a jegybank devizakötvény-vásárlási programja során rövid lejáratú kötvények vásárlásával igyekszik csökkenteni az államadósságot, a külföldi kitettséget, eliminálva azon hatásokat, amelyek a másodlagos piacon jelentkezhettek volna egy jelentősebb pozíció lezárásakor. A program meghirdetése óta a közvetlen külföldi tulajdonban lévő államadósság látványosan mérséklődött is.

Az állampapírpiacra való kényszerítéssel az MNB a fejlett országokban széles körben alkalmazott mennyiségi lazítás azon problémáját oldja meg, amely szerint hiába került papíron a gazdasági körforgásba a pénz, annak jelentős része valójában ki sem mozdult a jegybanki betétből. A magyar program rövid távú hatásaként érzékelhető a külföldi közvetlen adósságállomány csökkenése, ami mérsékli az államháztartás refinanszírozási kockázatait.

Az MNB a feltételes kamatswap-ügyletekkel tereli a bankokat az állampapírpiacra azáltal, hogy az ott elérhető fix kamatért cserébe változó kamatot fizet. Ez azt jelenti, hogy a piaci kamatcsökkenésnél a jegybanknak nyeresége, kamatemelkedés esetén vesztesége keletkezik. Ezzel tehermentesíti a bankokat a kamatkockázat alól. A piaci és kamatkockázat jegybanki mérlegbe emelése a monetáris lazítás nem konvencionális eszköze, amelyet a fejlett országok jegybankjai is elkerülhetetlenül használnak.

Ezen kockázat hosszú távra rögzítése a mérlegben komoly terhet jelenthet a jegybank, sőt később akár a költségvetés számára is egy kamatemelési periódus során. 
Különösen azért, mert a jelenlegi magyar államadósság tulajdonosi átszervezése - a külföldi finanszírozók hazaiakkal való helyettesítésére törekvés - miatt kiáramló jelentős külföldi tőke rövid távon gyengítőleg hat a forintra. Márpedig a forint gyengülése a jegybank nyereségének fö forrása.

Ezen túlmenően a program kockázata, hogy az állampapírpiac, így a költségvetés finanszírozása is nagyrészt a hazai bankrendszerre támaszkodik, ami végső soron kockáztatja a jövőbeli növekedést. Ha ugyanis baj van az állampapírok piacán, akkor baj lehet a bankrendszerben is, és ugyanez visszafelé is igaz. A bankrendszer problémája tehát az államháztartás problémája is lehet, ami veszélyeztetheti a jövőbeli hitelezési folyamatokat. Azt mondhatjuk, hogy az állam foglyul ejti a bankokat. A kormányzat ugyanakkor érdekeltebbé válhat abban, hogy valóságosan rendezze kapcsolatait a bankrendszerrel.

Az alacsony kamatkörnyezet jelentősen csökkentette az államháztartás kamatkiadásait, így ez jelentősen javítja az államháztartás mutatóit. Ez a hatás azonban csak átmeneti, ráadásul arra ösztönzi az államot, hogy rövidítse a futamidőket. Az átmeneti javulás és a rövidülő futamidők egyaránt a rövid távú szemlélet következményei.

A fejlett országokban tapasztalt lazítástól eltérően a hazai módszer csökkentőleg hat a jegybanki mérlegre, tehát a kamatkockázat emelkedését némileg ellensúlyozza az MNB mérlegének szúkülése. A kockázatok mérséklése céljából a jegybank megkezdte mérlegének csökkentését is. Ez azért releváns, mert az MNB eszközoldalán álló tételek hozama alacsonyabb, mint a forrásoldalon található kötelezettségek költsége, így minél kisebb a jegybank mérlege, annál kisebb a jegybank vesztesége. A jegybank a mérleg csökkentését a devizatartalék leépítésén keresztül képes elérni, ennek eredményeként a devizatartalék 40 százalékkal csökkent három év alatt. Ezzel párhuzamosan a jegybank mérlegének csökkenése ugyanakkor azonos a banki likviditás csökkentésével, jelen esetben a bankközi piac likviditásbőségének csökkentésével. Ez a csökkenés nagyban összefügg a devizahitelek forintra váltásával, és a hazai rövid lejáratú devizaadósság leépülésének következménye.

A monetáris politika hosszú távú célja vélhetően az évtizedek óta fennálló paszszív monetáris politika aktív oldalra állítása (betétek helyett hiteleken keresztül befolyásolni a monetáris kondíciókat). Ennek egyik lépése volt tehát a betétek korlátozása egy likviditásbő időszakban, míg a jegybank mérlegcsökkentése a likviditás felszívódását jelenti. Az aktív oldali beavatkozás általában hatékonyabb monetáris politikát jelent, és legfőképpen azt jelenti az MNB számára, hogy nyereséget érhet el egy kamatemelési időszakban. 


\section{A likviditás mint a monetáris transzmisszió csatornája}

Az új monetáris eszközök megjelenése nem csupán a finanszírozási korlátok elérése és a gyors beavatkozási kényszer következménye, hanem a monetáris transzmisszió változása és az új csatornák megjelenése miatt is szükségessé vált. A financializáció egyik korábban bemutatott következménye, hogy egyre nagyobb szerepük van a pénzügyi piacoknak nemcsak a forrásbevonás, hanem a megtakarítások esetében is. Egyre halványabb a határvonal a pénzügyi cégek és a nem pénzügyi vállalkozások magatartása között, a nem pénzügyi vállalatok is nyújtanak hitelt, portfóliót menedzselnek és banki hitel helyett akár kötvénykibocsátással finanszírozzák tevékenységüket. Ennek hatására felértékelődött a pénzügyi piacok likviditásának fontossága, ami a központi bankokat a végső hitelezői funkció (lender of last resort) felöl elmozdította a végső értékpapír-kereskedői funkció (dealer of last resort) felé (Mehrling, 2014). Ez azt jelenti, hogy a jegybank tölti be az árjegyző szerepet, amikor ezt más gazdasági szereplő nem teszi vagy nem tudja megtenni. A válságok idején ez tulajdonképpen értékpapír-vásárlást jelent, hogy ezzel segítse a gazdasági szereplök mérlegalkalmazkodását. Különösen fontos ez azon termékek piacán, amelyek fedezetül (collateral) szolgálnak a pénzpiaci műveletek esetében.

A fedezeti eszköz szerepkör elsősorban a bankközi piacokon kritikus fontosságú. Így a pénzintézetek közötti likviditás allokálásáért felelős pénzpiacok számára is nagyon fontos szerepe lett az egyéb pénzügyi eszközöknek. Az ilyen fedezeti eszközök többnyire hiteleszközök, amelyek a leginkább elfogadott fedezeti termékek. Ennek oka egyrészt, hogy a pénzpiaci ügyletekben alkalmazott termékekhez szimmetrikus információk szükségesek az értékpapír kifizetéseiről.

A fedezeti termék értékének változása tehát hatással van az érte kapott vagy adott likviditásra a pénzpiacon, így a pénzpiacon elérhető likviditás függ a fedezeti termék értékétől, annak volatilitásától és a fedezeti terméken alkalmazott diszkonttól, az úgynevezett haircuttól (ami szintén a volatilitástól és a termék likviditásától függ) (Youngman, 2009). Általában véve a hitelviszonyt megtestesítő értékpapírok, elsősorban az állampapírok bizonyulnak a legjobb fedezetnek, mivel ezek a legkevésbé információszenzitívek.

A monetáris politika szempontjából az eszközök likviditása is hatással van a beruházásokra, a vállalatok mérlegére, sőt a mérlegeken keresztül a hitelkapacitásokra és így a hitelkeresletre és a háztartások vagyonára is. 
Összefoglalás

A financializáció, a pénzügyi piacok és a pénzügyi szektor növekvő térnyerése a kapitalizmus fejlődésének természetes velejárója. A folyamatot azonban számos tényező gyorsította és segítette. Érvelésem szerint az egyik leginkább a folyamatot segítő tényező az 1970-es évektől alkalmazott piacfundamentalista gazdaságpolitika. A kockázatok értékpapírosítása és így a közvetítőrendszer szerepének mérséklődése a befektetői lojalitás csökkenésén és a növekvő kockázatéhségen keresztül elsősorban a rövid távú szemléletmód felerősödését hozta magával. A financializáció és az általa fokozódott rövid távú szemlélet gyorsította a globalizációs és integrációs folyamatokat, növelte a jövedelmi különbségeket és hatására rövidülnek és intenzívebbé válnak az üzleti ciklusok (gyorsabb növekedés, nagyobb összehúzódás), amely a 2008-2009-es pénzügyi válságban csúcsosodott. A válság pedig egyfajta katalizátorként funkcionálva olyan jelenségeket idézett elö, mint a globálisan alacsony kamatkörnyezet, valamint a kockázatkerülési csapda. Ezeket az eddig nem ismert monetáris jelenségeket új kreatív monetáris politikai eszközökkel igyekezett a világ kezelni, mivel a klasszikus eszközök nem eléggé hatékonyak az új jelenségek orvoslására azok természetéből fakadóan. Az elmúlt évek kutatásai középpontjába kerültek a cikk vizsgálatát képező jelenségek, azonban ezeket többnyire egymástól különálló tényezőként vizsgálták és vizsgálják, holott szorosan összekapcsolódó jelenségekről van szó, melyek a financializációra vezethetők vissza.

\section{Irodalomjegyzék}

Ábel István [2015]: A monetáris politika globális tendenciái és a stabilitási kockázatok. Közgazdasági Szemle, 2015. május. 62. évf., 3. sz., 284-304.

Allen, F. - Santomero, A. [1997]: The Theory of Financial Intermediation. Journal of Banking\& Finance, Vol. 21., Issues 11-12., 1461-1485. o.

Allen, F. - Santomero, A. [2001]: What do Financial Intermediaries do? Journal of Banking\& Finance, Vol. 25., Issue 2., 271-294. o.

Bean, C. - Broda, C. - Ito, T. - Kroszner, R. [2015]: Low for Long? Causes and Consequences of Persistently Low Interest Rates. Geneva Reports on the World Economy, 17.

Bélyácz Iván [2014]: A financializáció szerepe a globális pénzügyi válság kialakulásában. Hitelintézeti Szemle, 13. évf., 1. sz., 28-45. o.

Blinder, A. [2010]: How Central Should the Central Bank be? Journal of Economic Literature, Vol. 48., No. 1., 123-133. o.

Bresser-Pereira, L. C. [2010]: The Global Financial Crisis and After: A New Capitalism? Letölthető: www.bresserpereira.org.br.

Buiter, W. H. [2010]: Games of chicken between the monetary and fiscal authority: Who will control the deep pockets of the central bank? Citi Economics, Global Economics View, 21 July. 
Caballero, R. - Farhi, E. [2017]: The Safety Trap. Review of Economic Studies, Vol. 85., No. 1., February, 1-52. o.

Chodorow-Reich, G. [2014]: The Employment Effects of Credit Market Disruptions: Firm-level Evidence from the 2008-09 Financial Crisis. Quarterly Journal of Economics, Vol. 129., No. 1., 1-59. o.

Cornaggia, J. - Cornaggia, K. J. - Xia, H. [2016]: Revolving doors on Wall Street. Journal of Financial Economics, Vol. 120., Issue 2., 400-419. o.

Csontos László - Király Júlia - László Géza [1997]: Elfajzott-e a pénzügyi rendszer? Beszélő, III. folyam, 2. évfolyam., 7. sz. 18-30. o.

Dore, $R$. [2008]: Financialization of the global economy. Industrial and Corporate Change, Vol. 17., No. 6., 1097-1112. o.

Eggertsson, G. - Mehrotra, N. - Robbins, J. [2017]: A Model of Secular Stagnation: Theory and Quantitative Evaluation. NBER Working Paper, No. 23093.

Engelen, E. - Konings, M. [2008]: Financialization and the Political Economy of National Models: European Finance in the American Mirror. Paper presented at the workshop on Credit and Debt in Present Day Capitalism, University of Manchester, 13-14. March 2008.

Farmer, R. A. [2012]: The effect of conventional and unconventional monetary policy rules on inflation expectations: theory and evidence. Oxford Review of Economic Policy, Oxford University Press, Vol. 28., No. 4., 622-639. o., Winter.

French, S. - Leyshon, A. [2004]: The new, new financial system? Towards a conceptualization of financial reintermediation. Review of International Political Economy, Vol. 11., No. 2., 263-288. o.

Gertler, M. - Kiyotaki, N. [2010]: Financial Intermediation and Credit Policy in Business Cycle Analyses. In: Handbook of Monetary Economics, Vol. 3., 547-599. o.

Guillén, A. [2014]: Financialization and financial profit. Brazilian Journal of Political Economy, Vol. 34., No. 3., 451-470. o.

Halmosi Péter [2004]: Pénzügyi válságok a kilencvenes években - egy évtized tanulságai. In: Botos Katalin (szerk.): Pénzügyek a globalizációban. JATEPress, Szeged, 30-43. o.

Hanson, S. G, - Stein, J. G. [2015]: Monetary Policy and Long-Term Real Rates. Journal of Financial Economics, Vol. 115., No. 3., 429-448. o.

Hardie, I. [2008]: Financialization, Loyalty and the Rise of Short-Term Shareholder Value. ESRC Seminar, 'Financialization of Competitiveness'. Paper prepared for the ESRC Seminar, Financialization and competitieness

Heider, F. - Saidi, F. - Schepens, G. [2017]: Life below zero: Bank lending under negative policy rates. Working paper. Elérhetö: https://ssrn.com/abstract=2788204.

Horváth Dániel - Szini Róbert [2015]: A kockázatkerülési csapda - az alacsony kockázatú eszközök szűkösségének pénzügyi piaci és makrogazdasági következményei. Hitelintézeti Szemle, 14. évf., 1. sz., 111-138. o.

Joyce, M. - Miles, D. - Scott, A. - Vayanos, D. [2012]: Quantitative Easing and Unconventional Monetary Policy - an Introduction. The Economic Journal, Vol. 122., Issue 564., 271-288. o.

Kaplan, S. N. - Rauh, J. [2010]: Wall Street and Main Street: What contributes to the rise in the highest incomes? Review of Financial Studies, Vol. 23., No. 3., 1004-1050 o.

Kotz, M. D. [2008]: Neoliberalism and Financialization. Conference in honor of Jane D'Arista at the Political Economy Research Institute, University of Massachusetts Amherst.

Kotz, M. D. - McDonugh, T. [2008]: Global Neoliberalism and the Contemporary Social Structure of Accumulation. Megjelent: Understanding Contemporary Capitalism: Social Structure of Accumulation Theory for the Twenty First Century. Cambridge, Cambridge University Press. Szerk.: McDonough, Terrence - Reich, Michael - Kotz, David M.

Krippner, Greta [2005]: The Financialization of American Economy. Socio-Economic Review, Vol. 3., No. 1., 173-208. o. 
Lucca, D. - Seru, A. - Trebbi, F. [2014]: The revolving door and worker flows in banking regulation. Journal of Monetary Economics, Vol. 65., No. 3., 17-32. o.

Mehrling, P. [2014]: Why Central Banking Should be Re-Imagined. BIS Paper, No. 79.

O'Rourke, K. - Williamson, J. [1999]: Globalization and History: The Evolution of a Nineteenth Century Atlantic Economy. MIT Press, Cambridge.

Pete Péter [1999]: Gondolatok a pénzvilág uralmáról, a pénzügyi rendszer megnövekedett szerepéröl. Közgazdasági Szemle, XLVI. évf., 5. sz., 389-402. o.

Razin, A. - Sadka, E. - Woon Nam, C. [2005]: The Decline of the Welfare State: Demography and Globalization. MIT Press.

Razin, A. - Sadka, E. [2018]: Financial Globalization and the Welfare State. CEPR Discussion Paper, 12998.

Rodrik D. [2018]: Populism and the economics of globalization. NBER Working Paper, No. 23559.

Shive, A. A. - Forster, M. M. [2016]: The Revolving Door for Financial Regulators. Review of Finance, Vol. 21., Issue 4.

Szanyi M. [2018]: Müszaki fejlődés és hosszú távú gazdasági ciklusok. MTA Közgazdaság- és Regionális Tudományi Kutatóközpont, Világgazdasági Intézet, Mühelytanulmányok; 122.

Szunke, A. [2014]: The role of financialization in banking sector instability. Journal of Economics and Management, Vol. 16., No. 1. Department of Banking and Financial Markets, University of Economics in Katowice, 97-111. o.

Taylor, J. [2013]: International Monetary Policy Coordination: Past, Present and Future. BIS Working Paper, 43.

Tobin, J. [1984]: On the efficiency of the financial system. Lloyds Bank Review, Vol. 153., No.1., 1-15. o.

Velde, D. [2006]: Foreign Direct Investment and Development a Historical Perspective. Overseas Development Institute, 1-29. o.

Waller, C. J. [2016]: Negative interest rates: A tax in sheep's clothing. Federal Reserve Bank of St Louis.

Youngman, P. [2009]: Procyclicality and Value at Risk. Bank of Canada Financial System Review, 51-54. o.

Zysman, J. [1984]: Governments, markets, and growth: financial systems and the politics of industrial change. Cornell University Press. 